\title{
IMPROVEMENT OF WORK METHODS BASED ON MICROMOTION STUDY TO INCREASE TECHNICAL PRODUCTIVITY (Case Study at Nissan Ahmad Yani Surabaya Workshop)
}

\author{
YuniaDwieNurcahyanie ${ }^{*}$ \\ ${ }^{*}$ Industrial Engineering Department, Faculty of Industrial Technology \\ University of PGRI AdiBuana Surabaya \\ email :yuniadwie@unipasby.ac.id
}

\begin{abstract}
In the world of automotive innovation is not just about products, but services are also not less important always to be developed. Especially as it is today, people tend to like fast service but does not neglect the quality of the services provided. In this study using Micromotion Study, where technicians will be recorded every movement while using the old method of doing improvements to then be processed in order to generate new working methods that are more effective and efficient. Data retrieval is done by as much as 30 times on each experiment that is using the old methods and the new methods being used, the technicians then processed using computer software be Paired T-Test then the average productivity for the old method was 38.03 seconds/unit. Whereas with the new method have average 25.47 minutes/units, so that an increase in as much as $12.27 \mathrm{~min} /$ units or of $32.24 \%$. With productivity increases, then the unit enters the vehicle servicing technicians are carried out can also be increased. So a new method that is already done in the workshop workable Nissan Ahmad Yani Surabaya to further accelerate the servicing work, and can increase the unit entry service.
\end{abstract}

Keywords: MicromotionStudy, Productivity, Working Methods

\section{INTRODUCTION}

Nissan Ahmad Yani Surabaya is one of the companies engaged in the automotive field. This dealer is a dealer with 3s category (Sales, Service, Spare Parts), which can serve the sales of Nissan or Datsun vehicle units, service vehicles and spare parts sales. Of the three divisions of the dealer, the core part that produces services is the service division that acts to serve the repair and maintenance of the vehicle periodically. In doing its job, technicians are always required speed in completing periodical service of vehicles. Therefore at Nissan Ahmad Yani Surabaya has an Express Maintenance team consisting of 2 technicians who only specially perform Periodic Maintenance Service (PMS) without any complaints whatsoever. This team is very influential on the smooth flow of service vehicles that go into the workshop. Therefore, the working method used should always be improved to get a new working method in order for the unit to enter service vehicles can increase.

Sri Maryati et al (2012), the problem that occurs is that the company can only meet $75 \%$ existing production targets. By eliminating the waiting time, this study can speed up cycle time which initially takes 2.16 seconds to 1.83 seconds. This improvement has been successful in increasing the number of production.

Taufik dwi laksono (2010) it was concluded that one of the factors affecting the productivity of plasterers is the working method used and the time required for the activity. In the working method analysis it was found that the working method consisting of 11 activities required the total total time of the whole activity to be 616.1 seconds, resulting in productivity of $6 \mathrm{~m}^{2}$ /hour. While the working method that has 12 activities takes the total total time of the whole activity is 642.3 seconds so that productivity is generated at 5.4 $\mathrm{m}^{2} /$ hour. So it can be concluded that the working method used will affect the resulting productivity. 
M.Muhudhan (2013) conclude that the company did not apply ergonomic principles to the clothing manufacturing process, but the productivity of the company continued to decline because employees often experience illness due to work and accident. The results show that the role of ergonomics is very important for improving the productivity of the company. Implementation of ergonomics in the work method is to eliminate repetitive movement, using movement work according to the principle of economic movement. Implementation of ergonomics in tools and work facilities is to adjust the tool with posture. Implementation of ergonomics in the work environment is adequate lighting on the part of cloth cutting, noise control on the embroidery, ventilation settings at the sewing section. With proper training and instruction, the use of appropriate work protective equipment and ergonomic work systems, garment workers can produce products in safe and healthy workplaces and increase corporate productivity.

In the present study using the micromotion study method, which is a study of the movements undertaken by workers to complete the work. This method learns basic elements or subdivisions based on camerarecorded motion pictures, a timer that can accurately calculate the time intervals in a movie image. The micromotion study activity requires every movement in detail and gives the possibility of analyzing every movement that exists every detail and possible analysis of every movement that exists better than the visual motion study (Sritomo $\mathrm{W}$, quoted in Risma A 2008). By studying the recording of the old working method of express maintenance technician, will be obtained new method of working more effective and efficient for technician. Thus this study aims to prove that improvement of work methods based on micromotion study can increase the productivity of technicians.

\section{RESEARCH DESIGN}

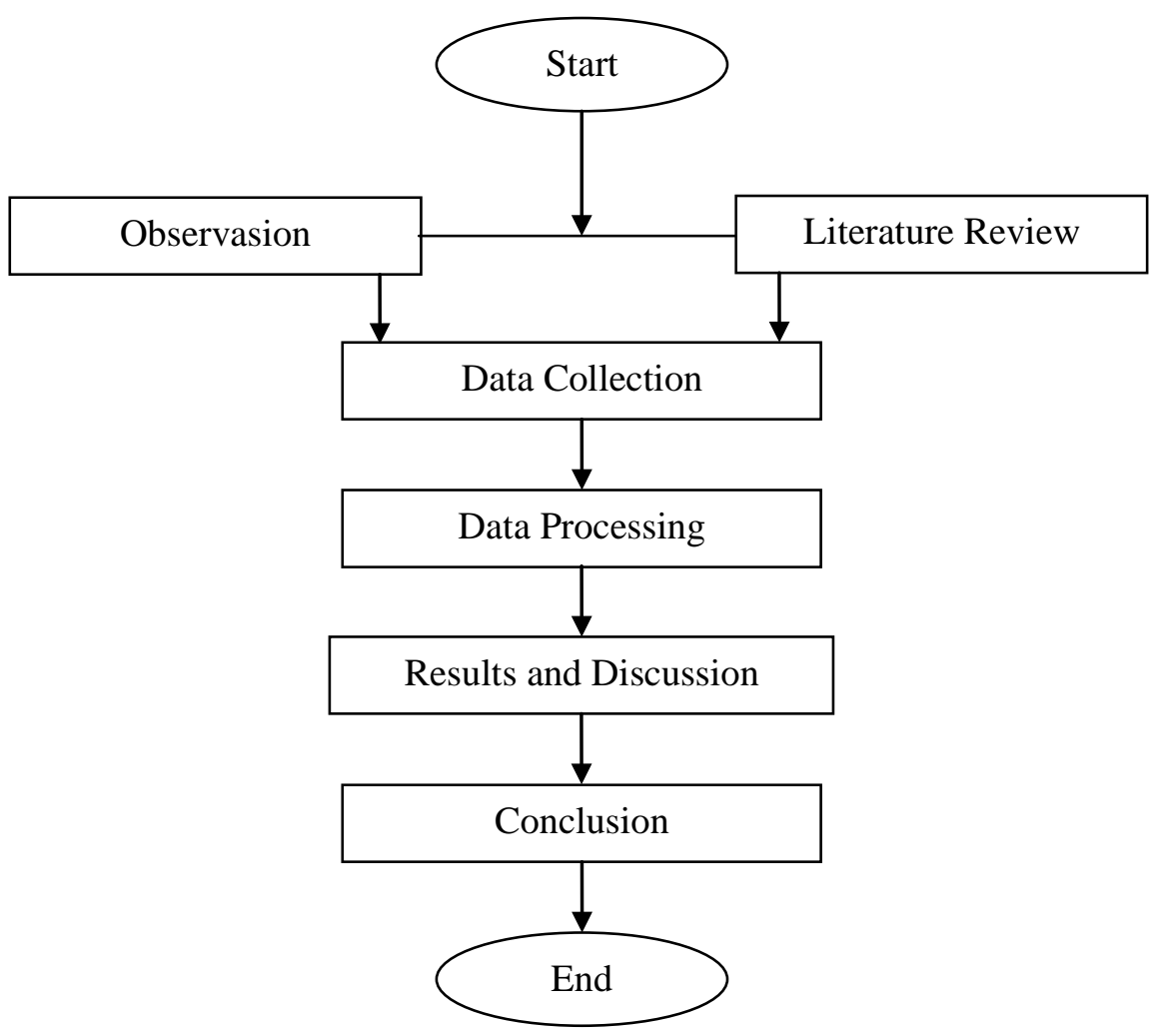


Figure 1. Flowchart

\section{DATA COLLECTION}

In this research has 2 variables, namely:

1. Working methods used by technicians Technicians at the Nissan Ahmad Yani garage already have a maintenance message sheet where this sheet contains details of work items that the technician must do in the service of the vehicle periodically, but no order has been set in doing each step of the job. This will be the main variable in performing the creation of new working methods for technicians in this study.

2. Productivity of technicians

Productivity is a term in production activity as a comparison between output (output) and input (input). According Herjanto 2007, productivity is a measure that states how well resources are regulated and utilized to achieve optimal results (Herjanto, quoted in Ardiawan 2016).

\section{DATA PROCESSING}

This observational study was conducted by using micromotion study method where the steps taken in consist of (Sritomo W, 2006):

1. Recording work movements of a technician's duty cycle that performs medium-to-moderate service repairs.

2. The movie image will be a permanent record that can be analyzed at any time and repeatedly as desired.

3. Draw the conclusions from the observed movement analysis of the film recording and depict it in the SIMO (Simultaneous Motion Chart) map showing the movements of the right hand and left hand as Table 1. The main purpose of this map is to try to balance work motion among others right hand or left hand in completing an activity

Table 1.SIMO Map (Simultaneous Motion Chart)

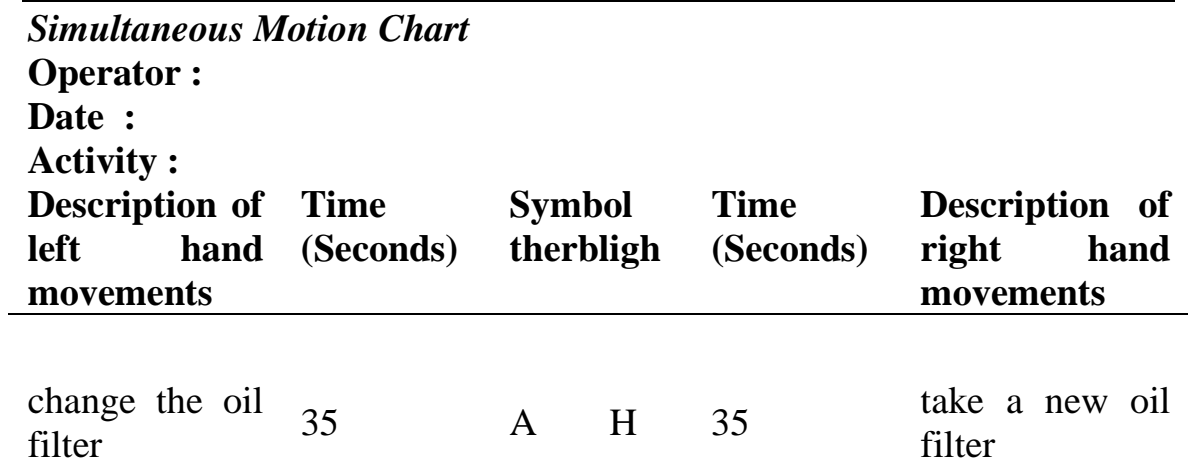

Source: Risma A. Simanjuntak, 2008

4. Establish better work movement alternatives by improving existing work methods in accordance with the motion economy principles.

The tools used in this research are audio visual movement recorder to know the productivity ratio between the old method and after the improvement of work method. the data to be retrieved is the old data of periodic category service work using the old method and the new method, the technician's reach data on the work station being the research object, the existing equipment data and easy to reach by the technician, compared with the data that technicians should need. Data analysis in this research using paired t-test method.

5. RESULTS AND DISCUSSION After doing the data collection and 
processing using micromotion study method obtained some variable differences between old method and new method used technician, as follows:

Table 2.Variable between old method and new method

\begin{tabular}{llll}
\hline No. & Variable & Old Method & New Method \\
\hline 1 & Number of technicians working on & 2 technician & 2 technician \\
2 & The position of the technician working & Right - Left & Front - Back \\
3 & Step lift use & 5 Steps & 4 Steps \\
4 & Number of equipment used & 24 item & 21 item \\
\hline
\end{tabular}

Source: Data Processing

From the results of the above table and then taken data in the form of time used by technicians in completing the work of periodic service type is using each method to then processed again with the method paired t-test to know the difference in time used. The result of paired t-test is:

Table 3.Results from Paired T-Test

\begin{tabular}{clll}
\hline \multicolumn{1}{c}{ Methods } & $\begin{array}{l}\text { Average } \\
\text { Completion Time }\end{array}$ & T-test & Sign. \\
\hline Old & 38,03 & 22,176 & \multirow{2}{*}{000} \\
New & 25,47 & &
\end{tabular}

Hypothesis:

$\mathrm{HO}=$ There is no difference in the average time of moderate category periodic service work using the old method and the new method.

$\mathrm{H} 1$ = There is a difference in average time of moderate category periodic service work using the old method and the new method.

Decision-making :

1. Based on t-count value

$\mathrm{H} 0$ is rejected if $\mathrm{t}<-2.045$ or $\mathrm{t}>2.045$

2. Based on the comparison of probability values (sig)

If probability $>0.05$ then $\mathrm{H} 0$ is accepted

If the probability is $<0.05$ then $\mathrm{H} 0$ is rejected

Decision: Through statistical calculation using SPSS in table 3 it can be concluded that t-count is 22.176 with value value (sig), 000. Therefore the value of tcount $>2.045$ and the value (sig), $000<0.05$ then $\mathrm{HO}$ is rejected, or the average time periodical category service is using the old method and the new method differs significantly positively. This means that the results of time periodic category service work using new methods more efficient than using the old method.

From the above opinion the researcher concludes that the work of periodic service of medium category by using new method is very influential in shorten the requirement of settlement time. It can be concluded from the result of experimental analysis of new method with the same controlling with the old method, the new method is able to shorten the average completion time of 12.27 minutes.

\section{CONCLUSION}

In the testing of PMS 20.000 or moderate servise, 30 experiments were performed using the old method and new method used by technician, the average productivity for the old method was 38,03 minutes / unit. While the new method has an average of 25.47 minutes / unit, resulting in an increase of 12,27 minutes / unit or $32,24 \%$. So it can be concluded that the improvement of working method using micromotion study can improve productivity marked by the increase of speed in doing the technician.

\section{REFERENCES}


TiBuana

Journal of applied Industrial Engineering-University of PGRI Adi Buana

p-ISSN 2622-2027

$e$-ISSN 2622-2035

1. Chandra, steven, 2013, perancanganstandart prosedur kerja dalam proses perakitan speaker tower di PT. Hartono Istana. Kudus

2. Darmawan .H, 2004, Pengantar Perancangan Teknik, Direktoral Jendral Pendidikan Tinggi; Jakarta

3. Poniman, 2012. Skripsi tugas akhir disain pembuatan alat penggiling daging quality funtion deployment. Surabaya.

4. Priyaanto, Duwi., 2012, Cara Kilat Belajar Analisis data dengan SPSS 20. Yogyakarta. Andy Offset.

5. Risma A. Simanjuntak, 2008 , Usulan Perbaikan MetodeKerjaBerdasarkanMicromot ion Study Dan Penerapan Metode 5s Untuk Meningkatkan Produktifitas.

6. Sugiyono, 2011. Metode Penelitian Kuantitatif, kualitatif dan $R \& D$. Bandung, Alfabeta.

7. Wignjosoebroto, Sritomo, 2006, Ergonomi Studi Gerak Dan Waktu. Surabaya, Penerbit Guna Widya 